\title{
Kualitas Air pada Irigasi Subak di Bali
}

\section{Quality of Water in Subak Irrigation in Bali}

\author{
I Gede Dumia Saputra, Sumiyati*, I Nyoman Sucipta \\ Program Studi Teknik Pertanian, Fakultas Teknologi Pertanian Universitas Udayana, Badung, Bali, Indonesia \\ *E-mail: sumiyati@unud.ac.id
}

\begin{abstract}
Abstrak
Air irigasi sangat berpengaruh pada budidaya subak. Kondisi pencemaran dalam air irigasi perlu diukur untuk mengetahui kualitas air untuk subak. Penelitian ini menentukan kualitas air irigasi untuk subak di Bali. Penelitian ini dilakukan pada tanggal 8 April hingga 8 Mei 2019 di 9 subak di 3 (tiga) kabupaten di Bali. Sampel air diambil di Subak Air Sumbul, Subak Yeh Anakan dan Subak Air Satang di Kabupaten Jembrana, Subak Guama, Subak Selan Bawak dan Subak Jatiluwih di Kabupaten Tabanan, Subak Tegal Kauh Selat, Subak Tohpati dan Subak Bugbug di Kabupaten Karangasem. Penelitian ini menggunakan metode survei dan dianalisis laboratorium. Hasil penelitian menunjukkan bahwa kualitas air irigasi diperoleh dibandingkan dengan standar kualitas air berdasarkan Peraturan Gubernur Bali Nomor 16 Tahun 2016 tentang standar kualitas air. Sampel air dilakukan pada dua titik di setiap subak, yaitu saluran inlet dan outlet. Parameter kualitas air adalah BOD, COD, DHL (Daya Hantar Listrik), pH, Nitrit ( $\mathrm{NO}_{2}$ ), Fosfat $\left(\mathrm{PO}_{4}\right)$ dan TDS (Total Dissolved Solids). Hasil tes tertinggi ditunjukkan oleh parameter: Parameter BOD nilainya $8.078 \mathrm{mg} / \mathrm{L}$ pada saluran inlet Subak Selat, parameter COD menunjukkan nilai $21.735 \mathrm{mg} / \mathrm{L}$ pada saluran inlet Subak Selat. Parameter DHL menunjukkan nilai $308 \mu \mathrm{mhos} / \mathrm{cm}$ di saluran inlet Subak Guama dan Subak Selan Bawak. Parameter pH menunjukkan nilai 8,40 pada saluran inlet Subak Bugbug. Parameter Nitrit menunjukkan nilai 2,606 mg / L pada saluran outlet Subak Guama. Parameter fosfat menunjukkan nilai 0,214 mg / L pada saluran inlet Subak Guama. Parameter TDS menunjukkan nilai 238 mg / L di saluran inlet dan outlet Subak Guama. Secara keseluruhan hasilnya masih sesuai dengan standar kualitas air kelompok IV untuk irigasi air.
\end{abstract}

Kata kunci: bod, cod, dhl, fosfat, irigasi, $p H$, nitrit, $t d s$.

\begin{abstract}
Irrigation water is very influential cultivative in subak. The condition of pollution in irrigation water needs to be measured in order to know the water quality for subak. This research determine to the quality of water irrigation for subak's in Bali. This research was conducted on April $8^{\text {th }}$ until May $8^{\text {th }} 2019$ at 9 subak in 3 (three) regency in Bali. The water sample was taken at Subak Air Sumbul, Subak Yeh Anakan and Subak Air Satang in Jembrana regency, Subak Guama, Subak Selan Bawak and Subak Jatiluwih in Tabanan regency, Subak Tegal Kauh Selat, Subak Tohpati and Subak Bugbug in Karangasem regency. This study used survey method and labolatory analyzed. The result of research showed that water irrigation quality obtained compared with the water quality standard based on Bali Governor Regulation Number 16 of 2016 concerning water standard quality. The water sample is done at two points on each subak, that is the inlet and outlet channels. Parameters of water quality is BOD, COD, EC (Electrical Conductivity), pH, Nitrite $\left(\mathrm{NO}_{2}\right)$, Phosphate $\left(\mathrm{PO}_{4}\right)$ and TDS (Total Dissolved Solids). The highest test result are shown by the parameters: BOD parameter the value is $8,078 \mathrm{mg} / \mathrm{L}$ at Subak Selat inlet channel, COD parameter show the value is $21,735 \mathrm{mg} / \mathrm{L}$ at Subak Selat inlet channel. EC parameter show the value is $308 \mu \mathrm{mhos} / \mathrm{cm}$ at Subak Guama and Subak Selan Bawak inlet channel. $\mathrm{pH}$ parameter show the value is 8,40 at Subak Bugbug inlet channel. Nitrite parameter show the value is $2,606 \mathrm{mg} / \mathrm{L}$ at Subak Guama outlet channel. Phosphate parameter show the value is $0,214 \mathrm{mg} / \mathrm{L}$ at Subak Guama inlet channel. TDS parameter show the value is $238 \mathrm{mg} / \mathrm{L}$ in outlet and innet channel of Subak Guama. Overall the result still in accordance with group IV water quality standar for water irrigation.
\end{abstract}

Keywords: irrigation: bod, cod, dhl, irrigation, $p H$, phosphate, nitrite, $t d s$.

\section{PENDAHULUAN}

Irigasi merupakan upaya penyediaan dan pengaturan air untuk memenuhi kepentingan pertanian dengan memanfaatkan air yang berasal dari permukaan maupun air tanah dan mendistribusinya secara sistematis (Takeda \& Sosrodarsono, 2003). Air merupakan sumber daya alam penting bagi kehidupan manusia. Khusus di bidang pertanian, air menjadi salah satu sumber penggerak agraria yang menduduki posisi strategis, khususnya pertanian sawah yang 
menjadi basis utama ketahanan pangan nasional. Selama dua dekade terakhir, sumber daya air mulai menjadi persoalan yang serius. Kondisi ini memiliki interrelasi yang sensitif dengan permasalahan lingkungan baik lingkup global, regional, maupun lokal. Air irigasi yang mengandung bahan pencemar seperti logam berat diduga dapat mempengaruhi kualitas produksi hasil pertanian. Banyak penggunaan pupuk kimia, pestisida dan herbisida telah menimbulkan pencemaran lingkungan, terancamnya keanekaragaman hayati pada lahan sawah, memburuknya kesehatan petani akibat dari keracunan penggunaan pestisida. Air yang digunakan sebagai sumber irigasi harus memenuhi syarat atau baku mutu kualitas air tertentu agar tidak membahayakan tanaman dan tidak mempengaruhi hasil tanaman dalam jangka waktu tertentu. Kualitas air irigasi ini dipengaruhi oleh kandungan sedimen dan unsur-unsur kimia yang terkandung di air (Schwab dkk, 1981 dalam Kurnia, 2004). Kualitas air irigasi yaitu kesesuaian air dalam memenuhi fungsinya untuk tanaman, kualitas air yang baik tidak akan menimbulkan masalah karena tidak mempengaruhi pertumbuhan tanaman dan hasil panen. Jika kualitas air buruk, pertumbuhan tanaman dan dampak pencemaran lingkungan yang ditimbulkan akan sulit untuk diatasi. Berdasarkan masalah yang ada dalam sistem irigasi, maka analisis kualitas air pada irigasi subak di Bali ditelaah dalam penelitian ini, dengan tujuan untuk mengetahui kesesuaiannya terhadap pertanian. dengan tujuan untuk mengetahui kesesuaiannya terhadap pertanian.

\section{METODE}

\section{Tempat dan Waktu Penelitian}

Lokasi penelitian dilakukan pada 3 kabupaten yang ada di Bali yaitu Kabupaten Jembrana, Tabanan, dan Karangasem, dengan 3 subak disetiap kabupaten. Subak tersebut meliputi Subak Air Sumbul, Subak Yeh Anakan, Subak Yeh Satang, Subak Guama, Subak Selan Bawak, Subak Jatiluwih, Subak Tegal Kauh Selat, Subak Tohpati Bebandem, dan Subak Desa Bugbug, sampel di ambil di saluran inlet dan outlet dan di uji di Laboratorium Analitik Universitas Udayana dan Laboratorium Pengelolaan Sumber Daya Alam Fakultas Teknologi Pertanian. Penelitian ini dilaksanakan pada tanggal 09 April 2019 sampai tanggal 08 Mei 2019.

\section{Alat dan Bahan Penelitian}

Alat yang digunakan pada penelitian ini adalah botol kapasitas 1,5 liter sebagai wadah penampung air irigasi, label nama, lemari inkubasi atau water cooler, suhu $20^{\circ} \mathrm{C}$, botol dari gelas $5 \mathrm{~L}-10 \mathrm{~L}$, labu ukur 100,0 $\mathrm{ml}$ dan 1000,0 ml, pH meter, DO meter yang terkalibrasi, shaker atau blander, oven, timbangan analitik, pemanas dengan lubang-lubang penyangga tabung (heating block), mikroburet, pipet ukur $5 \mathrm{ml}$, $10 \mathrm{ml}$ dan $25 \mathrm{ml}$, magnetic stirrer, EC meter, kertas tisu, spektrofotometer sinar tampak dengan kuvet silica, pipet volumetrik $1 \mathrm{ml}, 2 \mathrm{ml}, 5 \mathrm{ml}, 10 \mathrm{ml}, 20 \mathrm{ml}$, $25 \mathrm{ml}$ dan $50 \mathrm{ml}$, gelas piala $200 \mathrm{ml}$ dan $400 \mathrm{ml}$, erlenmeyer $250 \mathrm{ml}$, erlenmeyer $125 \mathrm{ml}$, gelas ukur 25 $\mathrm{ml}$ dan $50 \mathrm{ml}$, pipet tetes dan TDS meter.

Bahan yang digunakan pada penelitian ini adalah sampel air yang akan di uji, air bebas mineral dan Larutan nutrisi, larutan buffer fosfat, larutan magnesium sulfat, larutan kalsium klorida, larutan feri klorida, larutan suspensi bibit mikroba, larutan air pengencer, larutan glukosa-asam glutamat, larutan asam dan basa $1 \mathrm{~N}$, larutan asam sulfat, larutan natrium hidroksida, larutan natrium sulfit, inhibitor nitrifikasi allylthiourea (ATU), asam asetat, larutan kalium iodide 10\%, larutan indikator amilum (kanji), air bebas organik, larutan pereaksi asam sulfat, larutan baku Kalium Dikromat, larutan indikator ferroin, larutan baku Ferro Ammonium Sulfat, asam sulfamat, larutan baku Kalium Hidrogen Ftalat, akuades, air suling bebas nitrit, glass wool, kertas saring bebas nitrit berukuran pori $0,4 \mu \mathrm{m}$, larutan sulfanilamide, larutan NED Dihidroklorida, larutan natrium oksalat, larutan ferro ammonium sulfat, larutan induk nitrit, dan larutan kalium permanganat, larutan asam sulfat, larutan kalium antimonil tartrat, larutan ammonium molibdat, larutan asam askorbat, larutan campuran, dan kalium dihydrogen pospat anhidrat.

\section{Pelaksanaan Penelitian}

Pada penelitian ini terdapat beberapa tahapan yang dapat dijelaskan sebagai berikut.

\section{Pengambilan sampel}

Proses pengambilan sampel ini dilaksanakan secara bergilir disetiap Kabupaten. Setelah sampel diambil, sampel dibawa ke laboratorium untuk proses pengujian.

\section{Uji Laboratorium}

Pengujian sampel air irigasi menggunakan beberapa parameter yaitu:

\section{BOD}

Cara pengujian BOD adalah 2 (dua) buah botol DO disiapkan dengan menandai masing-masing botol dengan notasi $\mathrm{A}_{1}$ dan $\mathrm{A}_{2}$, kemudian larutan contoh uji dimasukan kedalam masing-masing botol $\mathrm{DO} \mathrm{A}_{1}$ dan $\mathrm{A}_{2}$ sampai meluap, masing-masing botol ditutup secara hati-hati untuk menghindari terbentuknya gelembung udara. Pengocokan dilakukan beberapa kali, kemudian menambahkan air bebas mineral pada sekitar mulut botol DO yang telah ditutup. Botol $\mathrm{A}_{2}$ disimpan kedalam lemari inkobator $20^{\circ} \mathrm{c} \pm 1^{\circ} \mathrm{c}$ selama 5 hari. Kemudian pengukuran oksigen terlarut dilakukan terhadap larutan dalam botol $\mathrm{A}_{1}$ dengan 
alat DO meter yang terkalibrasi. Hasil pengukuran adalah nilai oksigen terlarut nol hari $\left(\mathrm{A}^{1}\right)$. Pengukuran oksigen terlarut nol hari harus dilakukan paling lama 30 menit setelah pengenceran. Pengerjaan diulangi dengan botol $\mathrm{A}_{2}$ yang telah diinkubasi 5 hari \pm 6 jam, dan pengukuran yang diperoleh merupakan nilai oksigen terlarut 5 hari $\left(\mathrm{A}^{2}\right)$. Setelah itu ulangi pengerjaan pertama pada saat penyiapan 2 buah botol DO sampai siap untuk penetapan blanko dengan menggunakan larutan pengencer tanpa contoh uji. Hasil pengukuran yang diperoleh merupakan nilai oksigen terlarut nol hari $\left(B_{1}\right)$ dan oksigen terlarut 5 hari $\left(B_{2}\right)$. Kemudian pengerjaan awal sampai penetapan blanco dilakukan untuk penetapan kontrol standar dengan menggunakan larutam glukosa-asam glutamat. Hasil pengukuran yang diperoleh merupakan nilai oksigen terlarut nol hari $\left(C_{1}\right)$ dan oksigen terlarut 5 hari kemudian pengerjaan butir pertama sampai ke penetapan blanco (Pembacaan hasil uji) dilakukan kembali untuk beberapa macam pengenceran contoh uji.

\section{COD}

Cara pengujian COD adalah pipet volume contoh uji disiapkan kemudian ditambahkan digestion solution dan tambahkan larutan pereaksi asam sulfat kedalam tabung atau sampul. Tabung ditutup kemudian dikocok perlahan sampai homogen, tabung diletakan pada pemanas yang telah dipanaskan pada suhu $150^{\circ} \mathrm{c}$, digestion dilakukan selama 2 jam. Setelah itu contoh uji didinginkan secara perlahan yang sudah direfluks sampai suhu ruang. Saat didinginkan contoh uji ditutup kemudian dibuka setiap beberapa saat untuk mencegah tekanan gas, contoh uji dipindahkan secara kuantitatif dari tube atau sampul ke dalam Erlenmeyer untuk titrasi. Kemudian tambahkan indicator ferroin $0,05 \mathrm{ml}-0,1 \mathrm{ml}$ atau $1-2$ tetes, aduk dengan pengaduk magnetic sambil dititrasi dengan larutan baku FAS 0,05 M sampai terjadi perubahan warna yang jelas dari hijau-biru menjadi coklat kemerahan, kemudian volume larutan FAS yang digunakan dicatat. Setelah itu langkah pertama sampai akhir diulang terhadap air bebas organik sebagai blanko. Volume larutan FAS yang digunakan dicatat.

\section{DHL}

Cara mengukur daya hantar listrik adalah sampel air dan akuades diambil, dimasukan didalam wadah terpisah. Setelah itu alat ( EC meter) dihidupkan sampai layar muncul angka 0000, kemudian alat dicelupkan ke akuades (jangan melebihi batas ujung alat), alat dibersihkan lalu dicelupkan ke sampel air yang diuji setelah itu akan muncul angka pasti, lalu hasil uji dicatat.
pH

Cara pengujian $\mathrm{pH}$ adalah sampel air dan akuades diambil, dimasukan didalam wadah terpisah. Setelah itu tombol $O n$ ditekan untuk menghidupkan alat $(\mathrm{pH}$ meter), kemudian alat dicelupkan ke akuades (jangan melebihi batas ujung alat), alat dibersihkan lalu dicelupkan ke sampel air yang diuji, kemudian muncul angka pasti, lalu hasil uji dicatat.

\section{Nitrit $\left(\mathbf{N O}_{2}\right)$}

Cara uji Nitrit adalah contoh uji dimasukan kedalam pipet $50 \mathrm{ml}$ kemudian dimasukan kedalam gelas piala $200 \mathrm{ml}$, tambahkan $1 \mathrm{ml}$ larutan sulfanilamide, kocok dan dibiarkan 2 menit sampai dengan 8 menit. Setelah itu ditambahkan $1 \mathrm{ml}$ larutan NED dihidrochlorida, kocok, dibiarkan selama 10 menit kemudian segera melakukan pengukuran (pengukuran tidak boleh dilakukan lebih dari 2 jam), absorbansinya dibaca pada panjang gelombang $543 \mathrm{~nm}$.

\section{Pospat $\left(\mathrm{PO}_{4}\right)$}

Cara uji Pospat adalah contoh uji dimasukan kedalam pipet $50 \mathrm{ml}$ kemudian dimasukan kedalam erlenmeyer, 1 tetes indicator fenolftalin diasukan. Jika terbentuk warna merah muda, tambahkan tetes demi tetes $\mathrm{H}_{2} \mathrm{SO}_{4} 5 \mathrm{~N}$ sampai warna hilang kemudian $8 \mathrm{ml}$ larutan campuran ditambahkan dan dihomogenkan setelah itu dimasukan kedalam kuvet pada alat spektrofotometer, dibaca dan dicatat serapanya pada Panjang gelombang $880 \mathrm{~nm}$ dalam kisaran waktu antara 10 menit - 30 menit.

\section{TDS (Total Dissolve Solid)}

Cara uji TDS adalah sampel air dan akuades diambil, dimasukan didalam wadah terpisah. Setelah itu tombol On ditekan untuk menghidupkan alat (TDS meter), kemudian alat dicelupkan ke akuades (jangan melebihi batas ujung alat), alat dibersihkan lalu dicelupkan ke sampel air yang diuji, kemudian muncul angka pasti, lalu hasil uji dicatat.

\section{HASIL DAN PEMBAHASAN}

Dalam meneliti kualitas air pada irigasi subak, hasil uji kualitas air dibandingkan dengan baku mutu kualitas air sebagai acuan untuk menentukan kualitas air tersebut baik untuk subak. Parameter yang dipakai yaitu parameter fisik dan kimia anorganik.

\section{Kualitas Air Irigasi pada sistem subak Parameter BOD}

Nilai BOD yang didapatkan dibandingkan dengan baku mutu kualitas air irigasi yang dapat dilihat pada Tabel 1. Pada Tabel 1, dapat dilihat nilai BOD kualitas air irigasi yang baik untuk parameter BOD adalah kurang dari $12 \mathrm{mg} / \mathrm{L}$. Nilai BOD dari 9 sampel subak yang paling rendah adalah $3,299 \mathrm{mg} / \mathrm{L}$ yaitu pada saluran outlet Subak Tegal Kauh Selat 
Karangasem, sedangkan nilai BOD yang paling tinggi adalah $8,078 \mathrm{mg} / \mathrm{L}$ yaitu pada saluran inlet Subak Tegal Kauh Selat Karangasem.

Pada penelitian ini, ditemukan nilai BOD lebih tinggi pada saluran outlet dibandingkan dengan nilai BOD pada saluran inlet. Kondisi tersebut terjadi pada Subak Air Satang, dimana nilai BOD pada saluran inlet adalah 5,308 mg/L dan outlet 7,489 mg/L. Hal yang menyebabkan nilai BOD lebih tinggi pada saluran outlet adalah kandungan pupuk setelah pemupukan yang terbawa ke saluran outlet, limbah organik yang berada pada lahan sawah, dan adanya hama.

Tabel 1. Hasil uji pada parameter BOD

\begin{tabular}{clcccc} 
No & \multicolumn{1}{c}{ Nama subak } & Satuan & BOD (inlet) & BOD (outlet) & Baku mutu \\
$\mathbf{1}$ & Subak Guama (Tabanan) & $\mathrm{mg} / \mathrm{L}$ & 6,592 & 5,069 & $\leq 12$ \\
$\mathbf{2}$ & Subak Selan Bawak (Tabanan) & $\mathrm{mg} / \mathrm{L}$ & 7,408 & 6,108 & $\leq 12$ \\
$\mathbf{3}$ & Subak Jatiluwih (Tabanan) & $\mathrm{mg} / \mathrm{L}$ & 7,097 & 5,592 & $\leq 12$ \\
$\mathbf{4}$ & Subak Selat (Karangasem) & $\mathrm{mg} / \mathrm{L}$ & 8,078 & 3,299 & $\leq 12$ \\
$\mathbf{5}$ & Subak Tohpati (Karangasem) & $\mathrm{mg} / \mathrm{L}$ & 6,919 & 5,306 & $\leq 12$ \\
$\mathbf{6}$ & Subak Bugbug (Karangasem) & $\mathrm{mg} / \mathrm{L}$ & 7,898 & 4,725 & $\leq 12$ \\
$\mathbf{7}$ & Subak Air Sumbul (Jembrana) & $\mathrm{mg} / \mathrm{L}$ & 5,306 & 4,491 & $\leq 12$ \\
$\mathbf{8}$ & Subak Yeh Anakan (Jembrana) & $\mathrm{mg} / \mathrm{L}$ & 5,308 & 4,480 & $\leq 12$ \\
$\mathbf{9}$ & Subak Air Satang (Jembrana) & $\mathrm{mg} / \mathrm{L}$ & 5,308 & 7,489 & $\leq 12$ \\
\hline
\end{tabular}

Keterangan: Hasil uji laboratorium.

Pada beberapa sampel subak terdapat kondisi dimana nilai BOD pada saluran inlet lebih tinggi dibandingkan dengan nilai BOD pada saluran outlet. Kondisi tersebut terjadi pada Subak Selan Bawak dimana nilai BOD pada saluran inlet 7,408 $\mathrm{mg} / \mathrm{L}$ dan outlet $6,108 \mathrm{mg} / \mathrm{L}$. Hal yang menyebabkan nilai BOD lebih tinggi disaluran inlet adalah adanya aktivitas masyarakat seperti mencuci atau mandi di dalam aliran air irigasi, adanya limbah organik yang terbawa dalam air serta feses hewan yang terbuang terbawa oleh air irigasi.

Pada penelitian ini yang menyebabkan nilai BOD di 9 subak berbeda-beda adalah karena kandungan kebutuhan oksigen biokimia atau BOD atau banyaknya oksigen yang dibutuhkan oleh mikroorganisme untuk menguraikan bahan organiknya yang mudah terurai. Bahan organik yang tidak mudah terurai berasal dari limbah organik seperti dedaunan dan ranting pohon yang jatuh terbawa air irigasi, dan terkadang adanya bangkai hewan. Sehingga makin banyak bahan organik dalam air, maka makin besar BOD nya. Sedangkan nilai BOD nya rendah maka kandungan bahan organik didalam saluran air tersebut semakin menurun dikarenakan oksigen yang dibutuhkan oleh mikroorganisme untuk menguraikan bahan organiknya yang mudah terurai lebih rendah.

Berdasarkan nilai BOD yang diperoleh dari hasil uji laboratorium dari 9 sampel subak, dapat dinyatakan bahwa kondisi air irigasi pada subak sesuai dengan baku mutu kualitas air irigasi. Nilai BOD yang tidak melebihi baku mutu, maka sudah dapat diduga tidak ada indikasi pencemaran bahan organik. Mays (1996) mengartikan BOD sebagai suatu ukuran jumlah oksigen yang digunakan oleh populasi mikroba yang terkandung dalam perairan sebagai respon terhadap masuknya bahan organik yang dapat diurai. Dari pengertian-pengertian ini dapat dikatakan bahwa walaupun nilai BOD menyatakan jumlah oksigen, tetapi untuk mudahnya dapat juga diartikan sebagai gambaran jumlah bahan organik mudah urai (biodegradable organics) yang ada di perairan.

\section{Parameter COD}

Nilai COD pada penelitian ini dibandingkan dengan baku mutu kualitas air irigasi yang dapat dilihat pada Tabel 2. Pada Tabel 2, nilai COD kualitas air irigasi yang baik adalah kurang dari $100 \mathrm{mg} / \mathrm{L}$. Nilai COD dari 9 subak yang paling rendah adalah $16,032 \mathrm{mg} / \mathrm{L}$ yaitu pada saluran outlet Subak Selat Karangasem sedangkan nilai COD yang paling tinggi adalah $21,735 \mathrm{mg} / \mathrm{L}$ yaitu pada saluran inlet Subak Selat Karangasem.

Pada penelitian ini, ditemukan nilai COD lebih tinggi pada saluran outlet dibandingkan dengan nilai COD pada saluran inlet. Kondisi tersebut terjadi pada saluran inlet Subak Tohpati dimana nilai COD pada saluran inlet adalah $19,030 \mathrm{mg} / \mathrm{L}$ dan outlet Subak Tohpati $21,034 \mathrm{mg} / \mathrm{L}$. Hal yang menyebabkan nilai COD lebih tinggi pada saluran outlet adalah adanya limbah organik yang ada dalam sawah, pupuk yang terbawa oleh air, dan adanya hama dalam sawah.

Pada beberapa sampel subak terdapat kondisi dimana nilai COD pada saluran inlet lebih tinggi dibandingkan dengan nilai COD pada saluran outlet. Kondisi tersebut terjadi pada saluran inlet Subak Guama, dimana nilai COD pada saluran inlet adalah $20,052 \mathrm{mg} / \mathrm{L}$ dan saluran outlet Subak Guama 17,032 
mg/L. Hal yang menyebabkan nilai COD lebih tinggi pada saluran inlet adalah masyarakat masih memakai saluran air irigasi untuk mencuci atau mandi, adanya limbah yang terbawa dalam saluran air irigasi dan adanya bangkai hewan yang ada dalam saluran irigasi.

Tabel 2. Hasil uji pada parameter COD

\begin{tabular}{cl|c|cc|c} 
NO & \multicolumn{1}{|c|}{ NAMA SUBAK } & SATUAN & $\begin{array}{c}\text { COD } \\
\text { (INLET) }\end{array}$ & $\begin{array}{c}\text { COD } \\
\text { (OUTLET) }\end{array}$ & $\begin{array}{c}\text { BAKU } \\
\text { MUTU }\end{array}$ \\
\hline $\mathbf{1}$ & Subak Guama (Tabanan) & $\mathrm{mg} / \mathrm{L}$ & 20,052 & 17,032 & $\leq 100$ \\
$\mathbf{2}$ & Subak Selan Bawak (Tabanan) & $\mathrm{mg} / \mathrm{L}$ & 20,533 & 18,840 & $\leq 100$ \\
$\mathbf{3}$ & Subak Jatiluwih (Tabanan) & $\mathrm{mg} / \mathrm{L}$ & 20,214 & 16,191 & $\leq 100$ \\
$\mathbf{4}$ & Subak Selat (Karangasem) & $\mathrm{mg} / \mathrm{L}$ & 21,735 & 16,032 & $\leq 100$ \\
$\mathbf{5}$ & Subak Tohpati (Karangasem) & $\mathrm{mg} / \mathrm{L}$ & 19,030 & 21,034 & $\leq 100$ \\
$\mathbf{6}$ & Subak Bugbug (Karangasem) & $\mathrm{mg} / \mathrm{L}$ & 20,336 & 17,038 & $\leq 100$ \\
$\mathbf{7}$ & Subak Air Sumbul (Jembrana) & $\mathrm{mg} / \mathrm{L}$ & 21,034 & 22,035 & $\leq 100$ \\
$\mathbf{8}$ & Subak Yeh Anakan (Jembrana) & $\mathrm{mg} / \mathrm{L}$ & 18,029 & 22,536 & $\leq 100$ \\
$\mathbf{9}$ & Subak Air Satang (Jembrana) & $\mathrm{mg} / \mathrm{L}$ & 18,029 & 21,538 & $\leq 100$ \\
\hline
\end{tabular}

Keterangan: Hasil uji laboratorium.

Pada penelitian ini ditemukan nilai COD yang berbeda-beda, tinggi atau rendahnya kandungan COD dinyatakan karena semakin kecil oksigen yang dibutuhkan untuk mendegradasi beban pencemaran tersebut maka kandungan COD akan lebih rendah dan sebaliknya apabila membutuhkan banyak oksigen untuk menguraikan beban pencemaran pada air tersebut maka kandungan COD akan meningkat. Berdasarkan nilai BOD yang diperoleh dari hasil uji laboratorium dari 9 sampel subak, dapat dinyatakan bahwa kondisi air irigasi pada subak sesuai dengan baku mutu air irigasi.

COD atau Chemical Oxygen Demand adalah jumlah oksigen yang diperlukan untuk mengurai seluruh bahan organik yang terkandung dalam air (Boyd, 1990). Hal ini karena bahan organik yang ada sengaja diurai secara kimia dengan menggunakan oksidator kuat kalium bikromat pada kondisi asam dan panas dengan katalisator perak sulfat (Boyd, 1990; Metcalf \& Eddy, 1991), sehingga segala macam bahan organik, baik yang mudah urai maupun yang kompleks dan sulit urai, akan teroksidasi.

\section{Parameter DHL (Daya Hantar Listrik)}

Nilai DHL pada penelitian ini dapat dilihat pada Tabel 3.

Tabel 3. Hasil uji pada parameter DHL

\begin{tabular}{c|ll|ccc} 
NO & \multicolumn{1}{c|}{ NAMA SUBAK } & SATUAN & $\begin{array}{c}\text { DHL } \\
\text { (INLET) }\end{array}$ & $\begin{array}{c}\text { DHL } \\
\text { (OUTLET) }\end{array}$ & BAKU MUTU \\
\hline $\mathbf{1}$ & Subak Guama (Tabanan) & $\mu \mathrm{mhos} / \mathrm{cm}$ & 308 & 284 & $\leq 1800$ \\
$\mathbf{2}$ & Subak Selan Bawak (Tabanan) & $\mu \mathrm{mhos} / \mathrm{cm}$ & 308 & 286 & $\leq 1800$ \\
$\mathbf{3}$ & Subak Jatiluwih (Tabanan) & $\mu \mathrm{mhos} / \mathrm{cm}$ & 90 & 90 & $\leq 1800$ \\
$\mathbf{4}$ & Subak Selat (Karangasem) & $\mu \mathrm{mhos} / \mathrm{cm}$ & 234 & 234 & $\leq 1800$ \\
$\mathbf{5}$ & Subak Tohpati (Karangasem) & $\mu \mathrm{mhos} / \mathrm{cm}$ & 234 & 232 & $\leq 1800$ \\
$\mathbf{6}$ & Subak Bugbug (Karangasem) & $\mu \mathrm{mhos} / \mathrm{cm}$ & 274 & 254 & $\leq 1800$ \\
$\mathbf{7}$ & Subak Air Sumbul (Jembrana) & $\mu \mathrm{mhos} / \mathrm{cm}$ & 134 & 134 & $\leq 1800$ \\
$\mathbf{8}$ & Subak Yeh Anakan (Jembrana) & $\mu \mathrm{mhos} / \mathrm{cm}$ & 174 & 234 & $\leq 1800$ \\
$\mathbf{9}$ & Subak Air Satang (Jembrana) & $\mu \mathrm{mhos} / \mathrm{cm}$ & 234 & 172 & $\leq 1800$ \\
\hline
\end{tabular}

Keterangan: Hasil uji laboratorium.

Pada Tabel 3, nilai DHL kualitas air irigasi yang baik adalah kurang dari $1800 \mu \mathrm{mhos} / \mathrm{cm}$, nilai DHL yang paling rendah dari 9 sampel subak adalah 90 $\mu \mathrm{mhos} / \mathrm{cm}$ yaitu pada saluran inlet dan outlet Subak Jatiluwih Tabanan, sedangkan nilai DHL yang paling tinggi adalah $308 \mu \mathrm{mhos} / \mathrm{cm}$ yaitu pada saluran inlet Subak Guama dan Selan Bawak Tabanan.
Pada penelitian ini ditemukan nilai DHL lebih tinggi pada saluran outlet dibandingkan dengan nilai DHL pada saluran inlet. Kondisi tersebut ditemukan pada Subak Yeh Anakan $174 \mu \mathrm{mhos} / \mathrm{cm}$ dan outlet Subak Yeh Anakan $234 \mu \mathrm{mhos} / \mathrm{cm}$. Hal yang menyebabkan nilai DHL lebih tinggi pada saluran outlet adalah pupuk yang tidak dapat diserap oleh tanaman setelah 
itu terbawa dalam saluran air, pada saat pengambilan sampel lahan dalam keadaan pengolahan lahan, dan adanya limbah yang ada pada lahan.

Pada beberapa sampel subak terdapat kondisi dimana nilai DHL lebih tinggi pada saluran inlet dibandingan dengan nilai DHL pada saluran outlet. Kondisi ini ditemukan pada Subak Guama $308 \mu \mathrm{mhos} / \mathrm{cm}$ dan outlet Subak Guama $284 \mu \mathrm{mhos} / \mathrm{cm}$. Hal yang menyebabkan nilai DHL lebih tinggi di saluran inlet adalah adanya aktivitas masyarakat yang masih mencuci dan mandi karena deterjen dan sabun yang digunakan bisa mengakibatkan kandungan DHL itu tinggi, dan adanya limbah organik yang terbawa dalam air.
Berdasarkan nilai DHL yang diperoleh dari hasil uji laboratorium dari 9 sampel subak, dapat dinyatakan bahwa kondisi air pada subak sesuai dengan baku mutu kualitas air irigasi. Menurut Follet et.a; (1981) dalam Sipayung (2003), tingkat salinitas ini berarti garam terlarut sangat rendah. Dalam kondisi ini pengaruh kadar garam terlarut terhadap tanaman dapat diabaikan. Hal ini sama seperti yang disampaikan Ariyanto dan Widijanto (2008) bahwa nilai DHL yang tinggi didominasi oleh adanya garamgaram.

\section{Parameter pH}

Nilai $\mathrm{pH}$ pada penelitian ini dapat dilihat pada Tabel berikut.

Tabel 4. Hasil uji pada parameter $\mathrm{pH}$

\begin{tabular}{c|l|ccc} 
NO & \multicolumn{1}{|c|}{$\begin{array}{c}\text { pH } \\
\text { NAMA SUBAK }\end{array}$} & $\begin{array}{c}\text { pH } \\
\text { (INLET) }\end{array}$ & BAKU MUTU \\
\hline $\mathbf{1}$ & Subak Guama (Tabanan) & 8,06 & 7,91 & $5-9$ \\
$\mathbf{2}$ & Subak Selan Bawak (Tabanan) & 8,11 & 8,26 & $5-9$ \\
$\mathbf{3}$ & Subak Jatiluwih (Tabanan) & 7,11 & 7,81 & $5-9$ \\
$\mathbf{4}$ & Subak Selat (Karangasem) & 7,54 & 7,92 & $5-9$ \\
$\mathbf{5}$ & Subak Tohpati (Karangasem) & 7,76 & 8,03 & $5-9$ \\
$\mathbf{6}$ & Subak Bugbug (Karangasem) & 8,40 & 8,21 & $5-9$ \\
$\mathbf{7}$ & Subak Air Sumbul (Jembrana) & 7,98 & 7,56 & $5-9$ \\
$\mathbf{8}$ & Subak Yeh Anakan (Jembrana) & 7,84 & 7,53 & $5-9$ \\
$\mathbf{9}$ & Subak Air Satang (Jembrana) & 7,85 & 7,78 & $5-9$ \\
\hline
\end{tabular}

Keterangan: Hasil uji laboratorium.

Pada Tabel 4, nilai $\mathrm{pH}$ kualitas air irigasi yang baik adalah $\mathrm{pH} 5-9$, nilai $\mathrm{pH}$ yang paling rendah dari 9 sampel subak adalah $\mathrm{pH}$ 7,11 yaitu pada saluran inlet Subak Jatiluwih Tabanan dan nilai $\mathrm{pH}$ yang paling tinggi pada 9 sampel subak adalah $\mathrm{pH} 8,40$ yaitu pada saluran inlet Subak Bugbug Karangasem.

Nilai pH air irigasi pada semua titik inlet dan outlet masih sesuai dengan baku mutu kualitas air irigasi. Nilai $\mathrm{pH}$ yang lebih tinggi pada saluran inlet disebabkan oleh limbah organik seperti dedaunan dan ranting pohon yang jatuh terbawa air irigasi, kebiasaan masyarakat seperti mencuci dan mandi didalam air irigasi dan terkadang adanya bangkai hewan. Sedangkan yang menyebabkan nilai $\mathrm{pH}$ pada saluran outlet lebih tinggi disebabkan oleh adanya pengaruh pemberian pupuk dan pengambilan sampel air pada saat pengolahan lahan (Anonim, 2016).

Derajat keasaman $\mathrm{pH}$ merupakan logaritma negative dari konsentrasi ion-ion hydrogen yang terlepas dalam suatu cairan dan merupakan indikator baik dan buruknya suatu perairan. $\mathrm{pH}$ suatu perairan merupakan salah satu parameter kimia yang cukup penting dalam memantau kestabilan perairan (Simanjuntak, 2009). Skala pH bukanlah skala absolut, namun bersifat relative terhadap sekumpulan larutan standar yang pHnya ditentukan berdasarkan persetujuan internasional. Air murni bersifat netral, dengan pHnya pada suhu $25^{\circ} \mathrm{C}$ ditetapkan sebagai 7,0. Larutan dengan $\mathrm{pH}$ kurang daripada 7 disebut bersifat asam dan larutan dengan $\mathrm{pH}$ lebih daripada 7 dikatakan bersifat basa atau alkali.

\section{Parameter Nitrit $\left(\mathrm{NO}_{2}\right)$}

Nilai Nitrit kualitas air irigasi dapat dilihat pada Tabel 5. Pada penelitian ini peneliti memilih untuk menganalisis kualitas air irigasi menggunakan parameter nitrit karena peningkatan suatu usaha hasil pertanian yang kurang baik bisa berdampak negatif pada sumber daya air apabila kandungan nitrit terlalu tinggi, akan menyebabkan penurunan kualitas air dan sebagian besar air irigasi di saluran inlet masih dipakai untuk aktifitas masyarakat karena jika nitrit berlebih bisa bersifat toksik bagi organisme perairan. Nilai nitrit untuk baku mutu kualitas air irigasi yang dipakai sebagai acuan pada penelitian ini tidak terlalu dipersyaratkan, tetapi menurut Iskandar A. Yusuf (2014) baku mutu air irigasi nitrit pada air irigasi yang baik adalah $0,06 \mathrm{mg} / \mathrm{L}$. 
Tabel 5. Hasil uji pada parameter Nitrit

\begin{tabular}{clcc|cc} 
NO & \multicolumn{1}{c}{ NAMA SUBAK } & SATUAN & $\begin{array}{c}\text { NITRIT } \\
\text { (INLET) }\end{array}$ & $\begin{array}{c}\text { NITRIT } \\
\text { (OUTLET) }\end{array}$ & $\begin{array}{c}\text { BAKU } \\
\text { MUTU }\end{array}$ \\
$\mathbf{1}$ & Subak Guama (Tabanan) & $\mathrm{mg} / \mathrm{L}$ & 0,142 & 2,606 & - \\
$\mathbf{2}$ & Subak Selan Bawak (Tabanan) & $\mathrm{mg} / \mathrm{L}$ & 0,116 & 0,196 & - \\
$\mathbf{3}$ & Subak Jatiluwih (Tabanan) & $\mathrm{mg} / \mathrm{L}$ & 0,065 & 0,046 & - \\
$\mathbf{4}$ & Subak Selat (Karangasem) & $\mathrm{mg} / \mathrm{L}$ & 0,183 & 0,093 & - \\
$\mathbf{5}$ & Subak Tohpati (Karangasem) & $\mathrm{mg} / \mathrm{L}$ & 1,724 & 0,179 & - \\
$\mathbf{6}$ & Subak Bugbug (Karangasem) & $\mathrm{mg} / \mathrm{L}$ & 0,365 & 0,248 & - \\
$\mathbf{7}$ & Subak Air Sumbul (Jembrana) & $\mathrm{mg} / \mathrm{L}$ & 1,455 & 1,159 & - \\
$\mathbf{8}$ & Subak Yeh Anakan (Jembrana) & $\mathrm{mg} / \mathrm{L}$ & 1,578 & 1,563 & - \\
$\mathbf{9}$ & Subak Air Satang (Jembrana) & $\mathrm{mg} / \mathrm{L}$ & 1,578 & 0,225 & - \\
\hline
\end{tabular}

Keterangan: Hasil uji laboratorium.

Aktifitas masyarakat seperti mandi dan mencuci, kotoran ternak, hewan mati, pemakaian pupuk berlebih dan pestisida yang tidak sesuai menimbulkan pencemaran didalam air irigasi. Keterbatasan daya dukung dan daya lenting lingkungan akan menimbulkan pencemaran pada lingkungan perairan. Pada penelitian ini ditemukan nilai nitrit terendah pada 9 sampel subak adalah $0,065 \mathrm{mg} / \mathrm{L}$ yaitu pada saluran inlet Subak Jatiluwih dan $0,046 \mathrm{mg} / \mathrm{L}$ pada saluran outlet Subak Jatiluwih. Hal yang menyebabkan nilai nitrit rendah adalah Saluran inlet maupun outlet Subak Jatiluwih bisa memanfaatkan unsur N, P dan K dengan baik dan pemakaian pupuk yang lebih teratur dari hasil uji subak yang lainya.

Nilai nitrit yang paling tinggi di 9 sampel subak terjadi pada saluran outlet Subak Guama 2,606 mg/L. Menurut Rustadi (2009), hal ini terjadi karena pada saat pengambilan sampel lahan sedang dalam tahap pengolahan dengan kondisi air keruh, oleh karena itu dapat menyebabkan kandungan nitrit meningkat karena bahan organik terbawa dalam saluran air irigasi.

Konsentrasi nitrogen yang tinggi dapat menyebabkan terjadinya pertumbuhan fitoplankton yang berlebih atau eutrofikasi dan bisa menyebabkan pencemaran air waduk. Selain lingkungan abiotik, hasil transformasi nitrogen juga memberikan dampak negatif terhadap manusia. Nilai nitrit yang menunjukan angka tinggi pada saluran inlet akan kurang baik dipakai untuk aktifitas masyarakat karena bersifat toksik sedangkan nilai nitrit yang menunjukan angka yang lebih tinggi di saluran outlet kemungkinan disebabkan oleh jenis pupuk atau penggunaan pupuk seperti urea yang berlebih dan limbah organik yang ada dalam sawah, hal ini bisa menghambat kualitas atau pertumbuhan tanaman.

\section{Parameter Fosfat $\left(\mathrm{PO}_{4}\right)$}

Nilai Fosfat kualitas air irigasi dapat dilihat pada Tabel 6 berikut.

Tabel 6. Hasil uji pada parameter Fosfat.

\begin{tabular}{clcccc} 
NO & \multicolumn{1}{c}{ NAMA SUBAK } & SATUAN & $\begin{array}{c}\text { FOSFAT } \\
\text { (INLET) }\end{array}$ & $\begin{array}{c}\text { FOSFAT } \\
\text { (OUTLET) }\end{array}$ & BAKU MUTU \\
\hline $\mathbf{1}$ & Subak Guama (Tabanan) & $\mathrm{mg} / \mathrm{L}$ & 0,214 & 0,474 & $\leq 5$ \\
$\mathbf{2}$ & Subak Selan Bawak (Tabanan) & $\mathrm{mg} / \mathrm{L}$ & 0,191 & 0,180 & $\leq 5$ \\
$\mathbf{3}$ & Subak Jatiluwih (Tabanan) & $\mathrm{mg} / \mathrm{L}$ & 0,172 & 0,104 & $\leq 5$ \\
$\mathbf{4}$ & Subak Selat (Karangasem) & $\mathrm{mg} / \mathrm{L}$ & 0,168 & 0,097 & $\leq 5$ \\
$\mathbf{5}$ & Subak Tohpati (Karangasem) & $\mathrm{mg} / \mathrm{L}$ & 0,124 & 0,099 & $\leq 5$ \\
$\mathbf{6}$ & Subak Bugbug (Karangasem) & $\mathrm{mg} / \mathrm{L}$ & 0,147 & 0,162 & $\leq 5$ \\
$\mathbf{7}$ & Subak Air Sumbul (Jembrana) & $\mathrm{mg} / \mathrm{L}$ & 0,160 & 0,086 & $\leq 5$ \\
$\mathbf{8}$ & Subak Yeh Anakan (Jembrana) & $\mathrm{mg} / \mathrm{L}$ & 0,167 & 0,063 & $\leq 5$ \\
$\mathbf{9}$ & Subak Air Satang (Jembrana) & $\mathrm{mg} / \mathrm{L}$ & 0,167 & 0,079 & $\leq 5$ \\
\hline
\end{tabular}

Keterangan: Hasil uji laboratorium.

Pada Tabel 6, dapat dilihat bahwa nilai fosfat untuk baku mutu kualitas air irigasi yang baik adalah kurang dari $5 \mathrm{mg} / \mathrm{L}$. Nilai Fosfat dari 9 sampel subak yang paling rendah adalah $0,063 \mathrm{mg} / \mathrm{L}$ yaitu pada saluran outlet Subak Yeh Anakan Jembrana dan nilai fosfat yang paling tinggi adalah $0,214 \mathrm{mg} / \mathrm{L}$ pada saluran inlet Subak Guama Tabanan.

Pada penelitian ini ditemukan nilai fosfat lebih tinggi pada saluran outlet dibandingkan nilai fosfat pada saluran inlet. Kondisi tersebut terjadi pada saluran inlet Subak Guama 0,214 mg/L dan outlet Subak 
Guama $0,474 \mathrm{mg} / \mathrm{L}$. Hal yang menyebabkan nilai fosfat lebih tinggi pada saluran outlet adalah pada saat pengambilan sampel lahan masih dalam keadaan pengolahan lahan, pupuk yang belum terserap baik untuk tanaman terbawa dalam air, dan adanya limbah yang ada dalam sawah.

Pada beberapa sampel subak, terdapat kondisi dimana nilai fosfat pada saluran inlet lebih tinggi dibandingkan nilai fosfat pada saluran outlet. Kondisi ini terjadi pada saluran inlet Subak Selan Bawak $0,191 \mathrm{mg} / \mathrm{L}$ dan outlet Subak Selan Bawak 0,180 $\mathrm{mg} / \mathrm{L}$. Hal yang menyebabkan nilai Fosfat lebih tinggi di saluran inlet adalah masih adanya aktivitas masyarakat dalam mencuci dan mandi pada saluran irigasi, adanya limbah yang terbawa dalam air, dan feses hewan yang terbawa dalam air.

Berdasarkan nilai fosfat yang diperoleh dari hasil uji laboratorium dari 9 sampel subak, dapat dinyatakan bahwa kondisi air irigasi pada subak sesuai dengan baku mutu kualitas air irigasi. Kandungan fosfat yang tidak melebihi baku mutu air dapat dinyatakan baik untuk pertanian.

Fosfat merupakan senyawa yang sangat penting bagi kehidupan organisme. Namun demikian banyak aktifitas manusia yang menghasilkan fosfat dan dibuang ke lingkungan sebagai limbah. Limbah yang mengandung fosfat dapat masuk ke lahan subak melalui aliran irigasi. Fosfat organis dapat terjadi dari ortofosfat yang terlarut melalui proses biologis karena baik bakteri maupun tanaman menyerap fosfat bagi pertumbuhanya (Alaerts, 1987). Keberadaan fosfat dalam air sangat berpengaruh terhadap keseimbangan ekosistem perairan. Apabila kadar fosfat dalam air rendah $(<0,01 \mathrm{mg} \mathrm{P} / \mathrm{L})$, pertumbuhan ganggang akan terhalang, keadaan ini dinamakan oligotrop. Sebaliknya, apabila kadar fosfat tinggi pertumbuhan tanaman dan ganggang tidak terbatas lagi yang dinamakan keadaan eutrof, keadaan ini dapat mengurangi oksigen terlarut air. Hal ini tentu berbahaya bagi kelestarian ekosistem perairan. Selain itu buangan limbah organik seperti dedaunan, ranting pohon, feses hewan dan hasil degradasi bahan organik juga akan menghasilkan fosfat. Achmad (2004) menyebutkan bahwa selain dari hanyutan pupuk dan limbah domestik, hancuran bahan organik dan mineral fosfat berpengaruh terhadap konsentrasi fosfat.

\section{Parameter TDS (Total Dissolve Solid)}

Nilai TDS kualitas air irigasi bisa dilihat pada Tabel 7 berikut.

Tabel 7. Hasil uji pada parameter TDS

\begin{tabular}{c|lccc|c} 
NO & \multicolumn{1}{c}{ NAMA SUBAK } & SATUAN & $\begin{array}{c}\text { TDS } \\
\text { (INLET) }\end{array}$ & $\begin{array}{c}\text { TDS } \\
\text { (OUTLET) }\end{array}$ & $\begin{array}{c}\text { BAKU } \\
\text { MUTU }\end{array}$ \\
\hline $\mathbf{1}$ & Subak Guama (Tabanan) & $\mathrm{mg} / \mathrm{L}$ & 238 & 238 & $\leq 2000$ \\
$\mathbf{2}$ & Subak Selan Bawak (Tabanan) & $\mathrm{mg} / \mathrm{L}$ & 208 & 208 & $\leq 2000$ \\
$\mathbf{3}$ & Subak Jatiluwih (Tabanan) & $\mathrm{mg} / \mathrm{L}$ & 75 & 75 & $\leq 2000$ \\
$\mathbf{4}$ & Subak Selat (Karangasem) & $\mathrm{mg} / \mathrm{L}$ & 117 & 117 & $\leq 2000$ \\
$\mathbf{5}$ & Subak Tohpati (Karangasem) & $\mathrm{mg} / \mathrm{L}$ & 117 & 117 & $\leq 2000$ \\
$\mathbf{6}$ & Subak Bugbug (Karangasem) & $\mathrm{mg} / \mathrm{L}$ & 137 & 127 & $\leq 2000$ \\
$\mathbf{7}$ & Subak Air Sumbul (Jembrana) & $\mathrm{mg} / \mathrm{L}$ & 77 & 67 & $\leq 2000$ \\
$\mathbf{8}$ & Subak Yeh Anakan (Jembrana) & $\mathrm{mg} / \mathrm{L}$ & 87 & 117 & $\leq 2000$ \\
$\mathbf{9}$ & Subak Air Satang (Jembrana) & $\mathrm{mg} / \mathrm{L}$ & 117 & 86 & $\leq 2000$ \\
\hline
\end{tabular}

Keterangan: Hasil uji laboratorium.

Pada Tabel 7, dapat dilihat bahwa baku mutu kualitas air irigasi yang baik adalah kurang dari $2000 \mathrm{mg} / \mathrm{L}$. Nilai TDS dari 9 sampel subak yang paling rendah adalah $67 \mathrm{mg} / \mathrm{L}$ yaitu pada saluran outlet Subak Air Sumbul Jembrana dan nilai TDS yang paling tinggi adalah $238 \mathrm{mg} / \mathrm{L}$ pada saluran inlet dan outlet Subak Guama Tabanan.

Pada penelitian ini ditemukan nilai TDS lebih tinggi pada saluran outlet dibandingkan dengan nilai TDS pada saluran inlet. Kondisi tersebut terjadi pada saluran inlet Subak Yeh Anakan $87 \mathrm{mg} / \mathrm{L}$ dan saluran outlet Subak Yeh Anakan $117 \mathrm{mg} / \mathrm{L}$. Hal yang menyebabkan nilai TDS lebih tinggi pada saluran outlet adalah pupuk yang belum terserap tanaman terbawa dalam saluran air, dan adanya limbah dalam sawah tersebut.

Pada beberapa sampel subak, terdapat kondisi dimana nilai TDS pada saluran inlet lebih tinggi dibandingkan pada saluran outlet. Kondisi tersebut terjadi pada saluran inlet Subak Bugbug $137 \mathrm{mg} / \mathrm{L}$ dan saluran outlet Subak Bugbug $127 \mathrm{mg} / \mathrm{L}$. Hal yang menyebabkan nilai TDS lebih tinggi pada saluran inlet adalah masih adanya aktivitas masyarakat dalam mencuci dan mandi pada saluran irigasi, adanya limbah yang terbawa dalam saluran air irigasi dan adanya feses hewan yang terbawa dalam saluran air irigasi tersebut. 
Seperti yang dijelaskan oleh Effendi (2003) bahwa nilai TDS perairan sangat dipengaruhi oleh pengaruh antropogenik (berupa limbah domestik dan industri) beberapa padatan terlarut berasal dari material organik seperti daun, lumpur, plankton, limbah industri dan kotoran. Sumber-sumber lain berasal dari pupuk dan pestisida yang digunakan pada sawah dan peternakan. Selain itu Padatan Terlarut (Dissolved Solids) juga berasal dari bahan anorganik seperti batu dan udara yang mungkin mengandung kalsium bikarbonat, nitrogen, fosfor besi, sulfur, dan mineral lainnya. Sebagian besar dari bahan-bahan ini membentuk garam, yang merupakan senyawa yang mengandung keduanya yaitu logam dan non logam. Garam biasanya larut dalam air membentuk ion. Ion adalah partikel yang memiliki muatan positif atau negatif. Kandungan TDS ini berbanding lurus dengan tingkat kekeruhan di air, yaitu semakin tinggi TDS maka semakin tinggi tingkat kekeruhannya (Suryana, 2013) sedangkan semakin rendah TDS maka rendah tingkat kekeruhannya dan semakin rendah beban cemarannya.

\section{KESIMPULAN DAN SARAN}

\section{Kesimpulan}

Berdasarkan hasil penelitian yang telah dilakukan dapat diambil kesimpulan bahwa berdasarkan hasil uji kualitas air irigasi pada sembilan subak yang ada di Bali yaitu Subak Air Sumbul Jembrana, Subak Yeh Anakan Jembrana, Subak Yeh Satang Jembrana, Subak Guama Tabanan, Subak Selan Bawak Tabanan, Subak Jatiluwih Tabanan, Subak Tegal Kauh Selat Karangasem, Subak Tohpati Bebandem Karangasem, Subak Bugbug Karangasem dengan menggunakan Parameter BOD, COD, DHL, pH, Fosfat, dan TDS mendapatkan hasil bahwa hasil uji keseluruhan masih sesuai dengan Baku Mutu Kualitas Air Irigasi dengan menggunakan baku mutu air, sebagaimana yang diatur pada Peraturan Gubernur Bali Nomor 16 tahun 2016 tanggal 14 maret 2016.

Pada parameter Nitrit ditemukan hasil yang lebih tinggi, menurut Iskandar A. Yusuf (2014) standar kualitas air irigasi dinyatakan dengan nilai $0,06 \mathrm{mg} / \mathrm{L}$ sedangkan hasil yang lebih tinggi terjadi pada saluran outlet Subak Guama 2,606 mg/L yang disebabkan oleh saat pengambilan sampel lahan sedang dalam tahap pengolahan dengan kondisi air keruh, oleh karena itu dapat menyebabkan kandungan nitrit lebih tinggi karena bahan organik terbawa dalam saluran air irigasi.

Adanya aktifitas masyarakat dalam saluran irigasi, pembuangan limbah ke saluran irigasi, pemakaian pupuk berlebihan atau tidak sesuai yang menyebabkan hasil uji kualitas air irigasi mendapatkan hasil yang tidak menentu pada saluran inlet dan saluran outlet.

\section{Saran}

Adapun saran yang dapat diberikan pada penelitian ini adalah perlu adanya pengadaan alat Filtrasi Air Irigasi pada saluran inlet dan outlet untuk menghasilkan kualitas air yang lebih baik. Perlu adanya kesadaran masyarakat untuk tidak mencuci ataupun mandi di saluran irigasi, turut mengatur kegiatan gotong royong untuk membersihakan limbah pada saluran irigasi dan penggunaan pupuk yang baik dan cukup untuk tanaman. Perlu adanya penelitian lebih lanjut tentang perbandingan kualitas air irigasi di daerah pertanian dan non pertanian.

\section{DAFTAR PUSTAKA}

Achmad, R. 2004. Kimia lingkungan. Universitas Negeri Jakarta. Jakarta. $101 \mathrm{hlm}$.

Alaerts, G. dan Sri Santika Sumestri. 1987.Metode Penelitian Air.Usaha Nasional. Surabaya.

Anonim. (2016). Journal of Sustainable Agriculture . Caraka Tani, 31, 108-113.

Ariyanto DP dan Widijanto H 2008. Dampak air limbah industri Josroyo, Karanganyar terhadap kadar tembaga $(\mathrm{Cu})$ dalam air dan permukaan tanah saluran air Pungkuk.

Boyd, C.E. 1990. Water quality in ponds for aquaculture. Alabama AgriculturalExperiment Station, Auburn University, Alabama. 482 p.

Effendi, H. 2003. Telaah kualitas air bagi pengelolaan sumberdaya dan lingkungan perairan. Kanisius. Yogyakarta. 258 hal.

Iskandar A. Yusuf. 2014. Review of water quality criteria for irrigation. Jurnal Irigasi . Vol.9: 09.

Kurnia, U. 2004. Prospek Pengairan Pertanian Tanaman Semusim Lahan Kering. Jurnal Litbang Pertanian, 4(23): 130-138.

Mays, L.W.(Editor in Chief) 1996. Water resources handbook. McGraw-Hill.New York. p: 8.278.28 .

Metcalf \& Eddy, Inc. 1991.Wastewater engineering: Treatment, Disposal and Reuse, 3d ed. New York: McGraw-Hill.

Rustadi, R. (2009). Eutrofikasi Nitrogen Dan Fosfor Serta Pengendaliannya Dengan Perikanan Di Waduk Sermo (Eutrophication by Nitrogen and Phosphorous and Its Control Using Fisheries in Sermo Reservoir). Jurnal Manusia dan Lingkungan, 16(3), 176-186.

Sipayung, R. 2003. Stres Garam dan Mekanisme Toleransi Tanaman. USU Digital Library.http://library.usu.ac.id/download/fp/ 
bdp-rosita2.pdf(diakses pada 23 september 2019.

Simanjuntak, M. (2009). Hubungan faktor lingkungan kimia, fisika terhadap distribusi plankton di perairan Belitung Timur, Bangka Belitung. Jurnal Perikanan Universitas Gadjah Mada, 11(1), 31-45.

Takeda, K., \& Sosrodarsono, S. (2003). Hidrologi untuk Pengairan. Editor Sosrodarsono, S. PT Pradnya Paramita: Jakarta.
Suryana, Rifda. 2013. AnalisisKualitas Air Sumur Dangkal di Kecamatan Biringkanayya Kota (Tugas Akhir). Makassar: Jurusan Sipil Fakultas Teknik Universitas Hasanuddin.

Sutawan, N., 2005. Revitalisasi Subak Dalam Memasuki Era Globalisasi.Penerbit Andi Offset. Yogyakarta. 